HORNKE, NF; GADOTTI, GI; CAPILHEIRA, AF; CAVALCANTE, JA; NADAL, AP; SILVA, JG. 2020. Physiological potential of onion seeds stored in different packings and environments. Horticultura Brasileira 38: 312-318. http://dx.doi.org/10.1590/S0102-053620200312

\title{
Physiological potential of onion seeds stored in different packings and environments
}

\author{
Nander F Hornke ${ }^{1 \mathbb{D}}$; Gizele I Gadotti ${ }^{1} \mathbb{D}$; André F Capilheira ${ }^{1} \mathbb{D}$; Jerffeson A Cavalcante ${ }^{1} \mathbb{D}$; Ariele P \\ Nadal ${ }^{1} \mathbb{D}$; Joseano $G$ da Silva ${ }^{1} \mathbb{D}$
}

${ }^{1}$ Universidade Federal de Pelotas (UFPel), Pelotas-RS, Brasil; nanderhornke@gmail.com; gizeleingrid@gmail.com; capilheira@hotmail. com; jerffeson_agronomo@hotmail.com; arielenadal@hotmail.com; joseano_agronomo@outlook.com

\begin{abstract}
Storage is a fundamental step for maintaining seed quality after processing. Thus, in this study, we evaluated the physiological potential of onion seeds stored in different packings and environments. Impermeable, semi-permeable and permeable packings were tested under natural environment conditions $\left( \pm 19^{\circ} \mathrm{C}\right)$, cold and dry chamber $\left(10 \pm 2^{\circ} \mathrm{C}\right.$ and $\left.33 \% \mathrm{RH}\right)$ and cold chamber $\left(16 \pm 2^{\circ} \mathrm{C}\right.$ and $60 \%$ $\mathrm{RH})$, at $0,90,180,270$ and 360 days. The design was completely randomized in a $3 \times 3 \times 5$ factorial scheme, with three replicates. In order to evaluate emergency in field, a $3 \times 3$ factorial arrangement (packing $\mathrm{x}$ environment) was adopted. Onion seeds maintained their physiological quality when stored in impermeable packing for 360 days, regardless of the environment. The seeds' physiological quality was maintained in the other packings when stored in a cold or cold and dry chamber, with viability and vigor above $80 \%$ up to 180 days of storage.
\end{abstract}

Keywords: Allium cepa, hermetic packages, gas exchange.

\section{RESUMO}

Potencial fisiológico de sementes de cebola armazenadas em diferentes embalagens e ambientes

O armazenamento é uma etapa fundamental para a manutenção da qualidade das sementes após o beneficiamento. Desta forma, objetivou-se avaliar o potencial fisiológico de sementes de cebola armazenadas em diferentes embalagens e ambientes. Foram testadas as embalagens impermeável, semipermeável e permeável, nas condições de ambiente natural $\left( \pm 19^{\circ} \mathrm{C}\right)$, câmara fria e seca $\left(10 \pm 2^{\circ} \mathrm{C}\right.$ e $33 \%$ de UR) e câmara fria $\left(16 \pm 2^{\circ} \mathrm{C}\right.$ e $60 \%$ de UR), durante 0,90 , 180,270 e 360 dias. O delineamento foi inteiramente casualizado em esquema fatorial $3 \times 3 \times 5$, com três repetições. Para a avaliação da emergência em campo, adotou-se um fatorial 3x3 (embalagem $\mathrm{x}$ ambiente). As sementes de cebola mantiveram sua qualidade fisiológica quando armazenadas em embalagem impermeável durante 360 dias, independente do ambiente. A qualidade fisiológica das sementes foi mantida nas demais embalagens quando acondicionadas em câmara fria ou fria e seca, com viabilidade e vigor acima de $80 \%$ até os 180 dias de armazenamento.

Palavras-chave: Allium cepa, armazenamento hermético, trocas gasosas.

\section{Received on October 14, 2019; accepted on June 9, 2020}

$\mathrm{O}$ nion (Allium cepa) is considered one of the essential vegetables due to its consumption and economic value (Leite, 2014). Bulb onion production was approximately 119 thousand tons in 2018. Minas Gerais was the largest producer (37.36\%), followed by Paraná $(17.8 \%)$, Santa Catarina (13.7\%) and Rio Grande do Sul (12.4\%), according to IBGE (2018).

Considering onion a vegetable of significant global economic importance, using high-quality seeds with rapid seedling growth becomes a fundamental tool to reduce production costs and increase productivity. However, after reaching physiological maturity, the seeds begin a deterioration process that is inevitable and irreversible, resulting in abnormal seedlings and, invariably, death (González et al., 2012). This process is characterized by a set of physical, physiological, and biochemical events that start from physiological maturity in the field, and that can be aggravated in post-harvest due to the degree of seed moisture, temperature, and relative humidity (Marcos Filho, 2015).

Environmental humidity may cause physiological changes in seeds, since conditions of relative humidity and temperature, during storage, promote the hygroscopic balance of the seeds and determine the maintenance of their physiological quality for more or less time. It should be taken into consideration when it comes to storage and its effect on seed physiological potential (Catão et al., 2018).

Packings for storing seeds, available in the market, show permeable, semi-permeable, or impermeable characteristics, each with a different degree of protection concerning variations in air humidity and hygroscopicity (Baudet \& Villela, 2019). In order to keep the 
physiological potential and minimize damage deterioration process, the use of impermeable packing in storage can mitigate this process, keep the initial moisture content of seeds and decrease breathing and reserve degradation (Tonin \& Perez, 2006).

Thus, this set of factors creates a challenge for the seed industry, which should, somehow, improve storage, mainly in hot and humid tropical regions. Vegetable seed industries should be cautious, since vegetables have low storage potential, such as for onion (Rao et al., 2006).

In this study, we aimed to evaluate the physiological potential of onion seeds, stored in different packings, environments, and at different times.

\section{MATERIAL AND METHODS}

The trial was conducted from 2017 to 2018, at Universidade Federal de Pelotas, in Capão do Leão-RS. The average annual air temperature, rainfall, and humidity are $20^{\circ} \mathrm{C}, 1368 \mathrm{~mm}$ and $80.72 \%$, respectively, $18 \mathrm{~m}$ altitude. The authors used $1 \mathrm{~kg}$ of onion seeds, cultivar Crioula Precoce, harvested in 2016, 98\% initial germination, and 7\% moisture content, commercially acquired, and divided into 12 equal parts. Between harvest and experiment installation, the seeds were kept in hermetic plastic packages $(0.156 \mathrm{~mm}$ thickness) under environmental conditions.

Impermeable, semi-permeable and permeable packings were tested under natural environment conditions $\left( \pm 19^{\circ} \mathrm{C}\right)$, cold and dry chamber $\left(10 \pm 2^{\circ} \mathrm{C}\right.$ and $33 \%$ $\mathrm{RH})$ and cold chamber $\left(16 \pm 2^{\circ} \mathrm{C}\right.$ and $60 \% \mathrm{RH})$, at $0,90,180,270$ and 360 days. In the three environments, the packings were put on metallic shelves, at $1.20 \mathrm{~m}$ height. We used a $3 \times 3 \times 5$ factorial scheme, in a completely randomized design, with three replicates. In order to evaluate emergency in the field, a $3 \times 3$ factorial arrangement (packing $\mathrm{x}$ environment) was adopted, without considering time, due to local conditions.

Packings used showed the following characteristics: multilayer polyethylene of $0.156 \mathrm{~mm}$ thickness (impermeable), plastic packing (0.08 $\mathrm{mm}$ ) inside the cotton packing (semipermeable), according to the reseller recommendation and cotton packing (permeable). In order to evaluate the physiological potential of onion seeds, samples were collected in each period and the following tests were performed:

Moisture content: Approximately two $1 \mathrm{~g}$ samples of seeds were used, weighed with the aid of an analytical balance $(0.0001 \mathrm{~g})$ and placed in an oven with forced air circulation at $105 \pm 3^{\circ} \mathrm{C}$ temperature, during $24 \mathrm{~h}$ (Brazil, 2009).

First germination count [PCG (\%)], germination speed index (IVG) and germination test: three replicates of 50 seeds, uniformly distributed on blotting paper sheets, moistened 2.5 times the weight of the dry mass of the substrate; put in gerbox-type boxes $(10 \times 10 \times 3.5$ $\mathrm{cm}$ ) and kept in a germination controlled temperature room $\left(20 \pm 2^{\circ} \mathrm{C}\right)$. Daily counts started from the day when the radical protrusion began $( \pm 2 \mathrm{~mm})$ (IVG), according to Maguire (1962); normal seedlings were counted at 6 days after sowing [PCG (\%)] and counted at 12 days after sowing (Brazil, 2009).

Accelerated aging (EA): three replicates of 200 seeds of each treatment were evaluated using the gerbox method adapted. The seeds were uniformly distributed on a suspended aluminum screen; the screen was covered by voile fabric, inside the gerbox boxes, containing $40 \mathrm{~mL}$ saturated sodium chloride solution ( $40 \mathrm{~g}$ of $\mathrm{NaCl}$ in 100 $\mathrm{mL}$ distilled water), proposed by Jianhua \& McDonald (1996). Then, the boxes were placed in a BOD type chamber (EL 202/3), at $41^{\circ} \mathrm{C}$ for $72 \mathrm{~h}$. Afterward, a germination test was installed in an environment at $20 \pm 2^{\circ} \mathrm{C}$ temperature. The test was evaluated six days after sowing. The results were expressed in percentage of normal seedlings.

Emergency in the field (EC): due to climatic conditions and availability of space during storage, EC evaluation was carried out for only 360 days of storage. Three replicates of 200 seeds were used, sown in seedbeds, in lines spaced $12 \mathrm{~cm}$, at $1-\mathrm{cm}$ depth. Evaluation was done at 15 days after sowing, when the percentage of emerged seedlings kept constant. Moisture in seedbeds was kept with a water can, keeping the soil close to field capacity, determined through visual observations and touch.

Data were submitted to variance analysis $(p<0.05)$ using the $F$ test. Quantitative characteristics were compared using the Tukey test $(\mathrm{p}<0.05)$, and storage periods were evaluated through polynomial regression. For statistical analysis, Sisvar software version 5.3 was used.

\section{RESULTS AND DISCUSSION}

Triple interaction between the evaluated factors was noticed; thus, just one factor has a differentiated effect in the presence of each combination of environment, packing, and time. Seeds stored in impermeable packings showed hygroscopic balance (Table 1); this was noticed due to the value's stability throughout the evaluations. Hygroscopic balance was not verified when seeds were stored in semi-permeable and permeable packings in an uncontrolled environment along different storage periods, in any case. Therefore, maintaining the seeds' moisture content suggests that the environment does not provide significant effects on the physiological quality of seeds to the type of packing used.

According to Marcos Filho (2015), moisture is one of the factors most affecting the seeds' metabolic activity and, therefore, can determine the maintenance of embryonic viability and quality of seeds during storage. Water stimulates hydrolysis of macromolecules present in reserve tissues, causing these substances to promote the growth of embryos. Besides, seeds with low moisture content tend to keep physiological quality longer and low deterioration due to the reduction of metabolic activity (Umesha et al., 2016).

Evaluating the first germination count in different storage periods (Table 2), similar results were obtained up to 180 days $(\mathrm{p}>0.05)$ for the seeds in permeable packings in an uncontrolled environment, when a reduction in seed vigor was observed. However, for seeds 
Table 1. Moisture content and germination of onion seeds stored under different environments, packings and storage period. Pelotas, UFPel, 2018.

\begin{tabular}{|c|c|c|c|c|c|c|c|}
\hline \multirow{3}{*}{$\begin{array}{l}\text { Period } \\
\text { (days) }\end{array}$} & \multirow{3}{*}{$\begin{array}{c}\text { T }\left({ }^{\circ} \mathbf{C}\right) / \mathrm{UR} \\
(\%)\end{array}$} & \multicolumn{3}{|c|}{ Moisture content (\%) } & \multicolumn{3}{|c|}{ Germination (\%) } \\
\hline & & \multicolumn{3}{|c|}{ Packing } & \multicolumn{3}{|c|}{ Packing } \\
\hline & & IMP & SIMP & PER & IMP & SIMP & PER \\
\hline \multirow{3}{*}{0} & AMB & $7.0 \mathrm{Aa}^{1}$ & 7.0 Aaß & $7.0 \mathrm{Aa} \alpha$ & $98 \mathrm{Aa} \alpha$ & $98 \mathrm{Aa} \alpha$ & $98 \mathrm{Aa} \alpha \Sigma$ \\
\hline & $10 / 33$ & $6.9 \mathrm{Aa} \alpha$ & $7.0 \mathrm{Aa} \alpha \Sigma$ & 7.0 Aa $\Sigma$ & $98 \mathrm{Aa} \alpha$ & $98 \mathrm{Aa} \alpha$ & $98 \mathrm{Aa} \alpha$ \\
\hline & $16 / 60$ & $7.0 \mathrm{Aa} \alpha$ & $6.9 \mathrm{Aa} \alpha$ & $6.9 \mathrm{Aa} \Sigma$ & $98 \mathrm{Aa} \alpha$ & $98 \mathrm{Aa} \alpha$ & $98 \mathrm{Aa} \alpha$ \\
\hline \multirow{3}{*}{90} & AMB & $7.4 \mathrm{Ab} \alpha$ & $9.9 \mathrm{Aa} \alpha \Sigma$ & $10.0 \mathrm{Aa} \Sigma \Omega$ & 97 Аa $\alpha$ & $99 \operatorname{Aa} \alpha \Sigma$ & $95 \mathrm{Ba} \alpha$ \\
\hline & $10 / 33$ & $7.2 \mathrm{Aa} \alpha$ & 7.9 Ba $\alpha$ & $8.3 \mathrm{Ba} \alpha \Sigma$ & $98 \mathrm{Aa} \alpha$ & $98 \mathrm{Aa} \alpha$ & $99 \mathrm{Aa} \alpha$ \\
\hline & $16 / 60$ & $7.5 \mathrm{Aa} \alpha$ & 8.7 $\mathrm{Ba} \alpha$ & $7.2 \mathrm{Ba} \alpha \Sigma$ & $99 \mathrm{Aa} \alpha$ & $98 \mathrm{Aa} \alpha$ & $98 \mathrm{ABa} \alpha$ \\
\hline \multirow{3}{*}{180} & AMB & $7.5 \mathrm{Ab} \alpha$ & $8.6 \mathrm{Aa} \Omega \beta$ & $9.1 \mathrm{Aab} \Omega$ & $99 \mathrm{Aa \alpha}$ & $98 \mathrm{Aa} \Sigma \Omega$ & $92 \mathrm{Bb} \alpha$ \\
\hline & $10 / 33$ & $7.4 \mathrm{Aa} \alpha$ & $6.6 \mathrm{Ba} \alpha \Sigma$ & $7.4 \mathrm{Ba} \alpha \Sigma$ & $99 \mathrm{Aa} \alpha$ & $98 \mathrm{Aa} \alpha$ & $98 \mathrm{Aa} \alpha$ \\
\hline & $16 / 60$ & $6.7 \mathrm{Aa} \alpha$ & 7.2 $\mathrm{Ba} \alpha$ & $7.4 \mathrm{Ba} \alpha \Sigma$ & $98 \mathrm{Aa} \alpha$ & $98 \mathrm{Aa} \alpha$ & $98 \mathrm{Aa} \alpha$ \\
\hline \multirow{3}{*}{270} & AMB & $7.3 \mathrm{Ab} \alpha$ & $11.4 \mathrm{Aa} \Sigma$ & $11.5 \mathrm{Aa} \Sigma$ & $98 \mathrm{Aa} \alpha$ & $95 \mathrm{Bb} \beta$ & $89 \mathrm{Bc} \Sigma$ \\
\hline & $10 / 33$ & $7.4 \mathrm{Aa} \alpha$ & 7.5 Ba $\alpha$ & $7.9 \mathrm{Ba} \alpha \Sigma$ & $99 \mathrm{Aa} \alpha$ & $98 \mathrm{Aa} \alpha$ & $98 \mathrm{Aa} \alpha$ \\
\hline & $16 / 60$ & 7.7 Aa $\alpha$ & 8.2 $\mathrm{Ba} \alpha$ & $8.4 \mathrm{Ba} \alpha \Sigma$ & $99 \mathrm{Aa} \alpha$ & $98 \mathrm{Aa} \alpha$ & $98 \mathrm{Aa} \alpha$ \\
\hline \multirow{3}{*}{360} & AMB & 7.5 Ac $\alpha$ & 14.6 Aa $\alpha$ & $16.3 \mathrm{Aa} \alpha$ & $98 \mathrm{Aa \alpha}$ & $91 \mathrm{Bb} \Omega \beta$ & $84 \mathrm{Bc} \Omega$ \\
\hline & $10 / 33$ & $7.1 \mathrm{Aa} \alpha$ & $8.7 \mathrm{Ba} \Sigma$ & $9.0 \mathrm{Bb} \alpha$ & $99 \mathrm{Aa} \alpha$ & $98 \mathrm{Aa} \alpha$ & $98 \mathrm{Aa} \alpha$ \\
\hline & $16 / 60$ & $7.7 \mathrm{Aa} \alpha$ & $8.3 \mathrm{Ca} \alpha$ & $8.9 \mathrm{Ca} \alpha$ & $99 \mathrm{Aa} \alpha$ & $99 \mathrm{Aa} \alpha$ & $98 \mathrm{Aa} \alpha$ \\
\hline CV (\%) & & & 9.25 & & & 1.54 & \\
\hline
\end{tabular}

${ }^{1}$ Averages followed by the same letter, uppercase in columns, for each period and storage environment, lowercase in lines for packing $\mathrm{x}$ environment, and Greek in column for packing x time do not differ from each other, by the Tukey test at 5\% probability. AMB = room temperature, IMP = impermeable, SIMP = semi-permeable, $\mathrm{PER}=$ permeable.

in semi-permeable packing, a reduction in vigor was only observed at 270 days, around $20 \%$, and only $18 \%$ of normal seedlings, at 360 days. According to Martins et al. (2017), both PCG and IVG represent evidence of vigor in seed analysis. Evaluating the interaction between the three factors in this study (Table 2), the authors observed that the environment did not influence the quality of seeds. For semi-permeable and permeable packings, at 180 days, we verified a reduction in IVG of seeds kept in an uncontrolled environment, in any case.

Maintenance of vigor can be related to the fact that impermeable packings decrease fluctuations in moisture content and, consequently, increase biochemical and metabolic reactions (Umesha et al., 2016). José et al. (2010) found that chemical instability of lipids is a significant factor in reducing the speed of germination of various species, and that lipid peroxidation and oxidative stress cause seed deterioration during storage.

Concerning germination, regardless of the factors analyzed, the seeds showed germination higher than $80 \%$ (Table 1), according to Brasil's recommendation (2019). Nevertheless, at 180 days of storage, interaction time $\mathrm{X}$ permeable packing provided a $6 \%$ reduction in relation to other packings used in this study (Table 1). In controlled environments, germination did not show any significant reduction during storage over time, keeping values close to the initial quality, regardless of the type of packaging evaluated.

Evaluating storage of onion seeds with initial germination and moisture of $6.0 \%$ and $99 \%$, respectively, at $25^{\circ} \mathrm{C}$ temperature and laminated paper, Rao et al. (2006) verified maintenance of seed viability up to 12 months storage; those kept in cotton bag packing showed less than $70 \%$ germination after nine months. Costa et al. (2012) evaluating the germination of Crambe seeds in three different storage environments: cold chamber $\left(5 \pm 1^{\circ} \mathrm{C}\right)$, refrigerated chamber $\left(5 \pm 1^{\circ} \mathrm{C}\right)$, air-conditioned chamber $\left(18 \pm 1^{\circ} \mathrm{C}\right)$ and environmental condition $\left(26 \pm 3^{\circ} \mathrm{C}\right)$, verified higher germinative potential of seeds stored in the air-conditioned chamber up to twelve months.

Concerning the accelerated aging test, the authors observed an interaction between the evaluated factors (Table 2). It may indicate a differentiated effect of time, considering each combination of packing and storage environment, in a way that when analyzing time zero and at 90 days, the seeds did not show any significant difference in vigor, regardless of packing and environment. However, in other evaluation times, seeds stored in uncontrolled environment, and semipermeable and permeable packings were less vigorous than those kept in controlled environments.

According to the results obtained, the authors verified the efficiency of impermeable packing during the storage of onion seeds, considering that this 
fact is related to physical impairment imposed by the packing to external climatic variations of the environment during storage (Groot et al., 2012). Although irreversible and inevitable, seed quality losses can be slowed down according to storage conditions, such as packing and storage environment (Moncaleano-Escandon et al., 2013).

After evaluating seed moisture content throughout storage (Figure 1A) and being verified a significant effect for seeds stored in a non-controlled environment and cold chamber $\left(16^{\circ} \mathrm{C}\right.$ and $60 \% \mathrm{UR}$ ), unfolding was performed

Table 2. First germination count [PCG (\%)], germination speed index (IVG), accelerated aging [EA (\%)] and emergency in the field [EC $(\%)]$ of onion seeds stored under different environments, packings and storage periods. Pelotas, UFPel, 2018.

\begin{tabular}{|c|c|c|c|c|c|c|c|}
\hline \multirow{3}{*}{$\begin{array}{l}\text { Periods } \\
\text { (days) }\end{array}$} & \multirow{3}{*}{$\begin{array}{c}\text { T }\left({ }^{\circ} \mathbf{C}\right) / \\
\text { UR }(\%)\end{array}$} & \multicolumn{3}{|c|}{ PCG (\%) } & \multicolumn{3}{|c|}{ IVG } \\
\hline & & \multicolumn{3}{|c|}{ Packing } & \multicolumn{3}{|c|}{ Packing } \\
\hline & & IMP & SIMP & PER & IMP & SIMP & PER \\
\hline \multirow{3}{*}{0} & AMB & $97 \mathrm{Aa} \alpha$ & $97 \mathrm{Aa} \alpha$ & $97 \mathrm{Aa} \alpha$ & $28.56 \mathrm{Aa} \alpha$ & $28.56 \mathrm{Aa} \alpha$ & $28.56 \mathrm{Aa} \alpha$ \\
\hline & $10 / 33$ & $97 \mathrm{Aa}$ & $97 \mathrm{Aa} \alpha$ & $97 \mathrm{Aa} \alpha$ & $28.56 \mathrm{Aa} \alpha$ & $28.56 \mathrm{Aa} \alpha$ & $28.56 \mathrm{Aa} \alpha$ \\
\hline & $16 / 60$ & $97 \mathrm{Aa}$ & $97 \mathrm{Aa} \alpha$ & $97 \mathrm{Aa} \alpha$ & $28.56 \mathrm{Aa} \alpha$ & $28.56 \mathrm{Aa} \alpha$ & $28.56 \mathrm{Aa} \alpha$ \\
\hline \multirow{3}{*}{90} & $\mathrm{AMB}$ & $93 \mathrm{Aa} \alpha$ & $96 \mathrm{Aa} \alpha$ & $96 \mathrm{Aa} \alpha$ & $27.03 \mathrm{Ab} \alpha$ & $28.44 \mathrm{Aa} \alpha$ & $28.00 \mathrm{Aab} \alpha$ \\
\hline & $10 / 33$ & $96 \mathrm{Aa}$ & $95 \mathrm{Aa} \alpha$ & $94 \mathrm{Aa} \alpha$ & $28.00 \mathrm{Aa} \alpha$ & $28.56 \mathrm{Aa} \alpha$ & $28.60 \mathrm{Aa} \alpha$ \\
\hline & $16 / 60$ & $95 \mathrm{Aa}$ & $95 \mathrm{Aa} \alpha$ & $95 \mathrm{Aa \alpha}$ & $28.34 \mathrm{Aa} \alpha$ & $27.87 \mathrm{Aa} \alpha \Sigma$ & $28.20 \mathrm{Aa} \alpha$ \\
\hline \multirow{3}{*}{180} & AMB & $94 \mathrm{Aa} \alpha$ & $93 \mathrm{Aa} \alpha \Sigma$ & $70 \mathrm{Bb} \Sigma$ & $27.84 \mathrm{Aa} \alpha$ & $24.40 \mathrm{Cb} \Sigma$ & $18.31 \mathrm{Bc} \Sigma$ \\
\hline & $10 / 33$ & $94 \mathrm{Aa}$ & $95 \mathrm{Aa} \alpha$ & $95 \mathrm{Aa} \alpha$ & $28.63 \mathrm{Aa} \alpha$ & $28.38 \mathrm{Aa} \alpha$ & $28.63 \mathrm{Aa} \alpha$ \\
\hline & $16 / 60$ & $97 \mathrm{Aa}$ & $97 \mathrm{Aa} \alpha$ & $97 \mathrm{Aa} \alpha$ & $28.51 \mathrm{Aa} \alpha$ & $26.78 \mathrm{Ba} \Sigma \Omega$ & $27.38 \mathrm{Aa} \alpha$ \\
\hline \multirow{3}{*}{270} & AMB & $96 \mathrm{Aa} \alpha$ & $89 \mathrm{Bb} \Sigma$ & $20 \mathrm{Bc} \Omega$ & $24.57 \mathrm{Aa} \Sigma$ & $20.25 \mathrm{Bb} \Omega$ & $15.14 \mathrm{Bb} \Omega$ \\
\hline & $10 / 33$ & $97 \mathrm{Aa}$ & $97 \mathrm{Aa} \alpha$ & $97 \mathrm{Aa} \alpha$ & $24.85 \mathrm{Aa} \Sigma$ & $24.92 \mathrm{Aa} \Sigma$ & $24.94 \mathrm{Aa} \Sigma$ \\
\hline & $16 / 60$ & $97 \mathrm{Aa}$ & $98 \mathrm{Aa} \alpha$ & $97 \mathrm{Aa} \alpha$ & $25.11 \mathrm{Aa} \Sigma$ & $24.96 \mathrm{Aa} \Omega$ & $24.38 \mathrm{Aa} \Sigma$ \\
\hline \multirow{3}{*}{360} & $\mathrm{AMB}$ & $97 \mathrm{Aa} \alpha$ & $73 \mathrm{Bb} \Omega$ & $18 \mathrm{Bc} \Omega$ & $21.67 \mathrm{Aa} \Omega$ & $15.25 \mathrm{Bb} \beta$ & $12.77 \mathrm{Bc} \beta$ \\
\hline & $10 / 33$ & $97 \mathrm{Aa}$ & 96 Аa $\alpha$ & $97 \mathrm{Aa} \alpha$ & $22.29 \mathrm{Aa} \Omega$ & $21.72 \mathrm{Aa} \Omega$ & $22.12 \mathrm{Aa} \Omega$ \\
\hline & $16 / 60$ & $98 \mathrm{Aa}$ & $97 \mathrm{Aa} \alpha$ & $97 \mathrm{Aa} \alpha$ & $22.08 \mathrm{Aa} \Omega$ & $21.87 \mathrm{Aaß}$ & $22.02 \mathrm{Aa} \Omega$ \\
\hline \multirow[t]{3}{*}{ CV (\%) } & & \multicolumn{3}{|c|}{2.70} & \multicolumn{3}{|c|}{2.72} \\
\hline & & \multicolumn{3}{|c|}{ EA (\%) } & \multicolumn{3}{|c|}{ EC (\%) } \\
\hline & AMB & $94 \mathrm{Aa} \alpha$ & $94 \mathrm{Aa} \alpha \Sigma$ & $94 \mathrm{Aa} \alpha$ & - & - & - \\
\hline \multirow[t]{2}{*}{0} & $10 / 33$ & $94 \mathrm{Aa} \alpha$ & $94 \mathrm{Aa} \alpha$ & $94 \mathrm{Aa} \alpha$ & - & - & - \\
\hline & $16 / 60$ & $94 \mathrm{Aa} \alpha$ & $94 \mathrm{Aa} \alpha$ & $94 \mathrm{Aa} \alpha$ & - & - & - \\
\hline \multirow{3}{*}{90} & $\mathrm{AMB}$ & $96 \mathrm{Aa} \alpha$ & $96 \mathrm{Aa} \alpha$ & $95 \mathrm{Aa} \alpha$ & - & - & - \\
\hline & $10 / 33$ & $97 \mathrm{Aa} \alpha$ & $97 \mathrm{Aa} \alpha$ & $97 \mathrm{Aa} \alpha$ & - & - & - \\
\hline & $16 / 60$ & $96 \mathrm{Aa} \alpha$ & $97 \mathrm{Aa} \alpha$ & $96 \mathrm{Aa} \alpha$ & - & - & - \\
\hline \multirow{3}{*}{180} & AMB & $96 \mathrm{Aa} \alpha$ & $88 \mathrm{Bb} \Sigma$ & $76 \mathrm{Bc} \Sigma$ & - & - & - \\
\hline & $10 / 33$ & $97 \mathrm{Aa} \alpha$ & $97 \mathrm{Aa} \alpha$ & $97 \mathrm{Aa} \alpha$ & - & - & - \\
\hline & $16 / 60$ & $96 \mathrm{Aa} \alpha$ & $95 \mathrm{Aa} \alpha$ & $95 \mathrm{Aa} \alpha$ & - & - & - \\
\hline \multirow{3}{*}{270} & $\mathrm{AMB}$ & $89 \mathrm{Ba} \alpha$ & $76 \mathrm{Bb} \Omega$ & $41 \mathrm{Bc} \Omega$ & - & - & - \\
\hline & $10 / 33$ & $96 \mathrm{Aa} \alpha$ & $97 \mathrm{Aa} \alpha$ & $94 \mathrm{Aa} \alpha$ & - & - & - \\
\hline & $16 / 60$ & $96 \mathrm{Aa} \alpha$ & $94 \mathrm{Aa} \alpha$ & $92 \mathrm{Aa} \alpha$ & - & - & - \\
\hline \multirow{3}{*}{360} & AMB & $76 \mathrm{Ba} \Sigma$ & $23 \mathrm{Bb} \beta$ & $17 \mathrm{Bc} \beta$ & $85 \mathrm{Aa}$ & $70 \mathrm{Aa}$ & $40 \mathrm{Bb}$ \\
\hline & $10 / 33$ & $86 \mathrm{Aa} \Sigma$ & $86 \mathrm{Aa} \Sigma$ & $82 \mathrm{Aa} \Sigma$ & $74 \mathrm{Aa}$ & $81 \mathrm{Aa}$ & $90 \mathrm{Aa}$ \\
\hline & $16 / 60$ & $90 \mathrm{Aa} \alpha$ & $85 \mathrm{Aa} \Sigma$ & $76 \mathrm{Ab \Sigma}$ & $84 \mathrm{Aa}$ & $82 \mathrm{Aa}$ & $86 \mathrm{Aa}$ \\
\hline CV (\%) & & & 3.95 & & & 15.57 & \\
\hline
\end{tabular}

${ }^{1}$ Averages followed by the same letter, uppercase in columns, for each period and storage environment, lowercase in lines for packing $\mathrm{x}$ environment, and Greek in column for packing x time do not differ from each other, by the Tukey test at 5\% probability. AMB $=$ room temperature, $\mathrm{IMP}=$ impermeable, $\mathrm{SIMP}=$ semi-permeable, $\mathrm{PER}=$ permeable. 

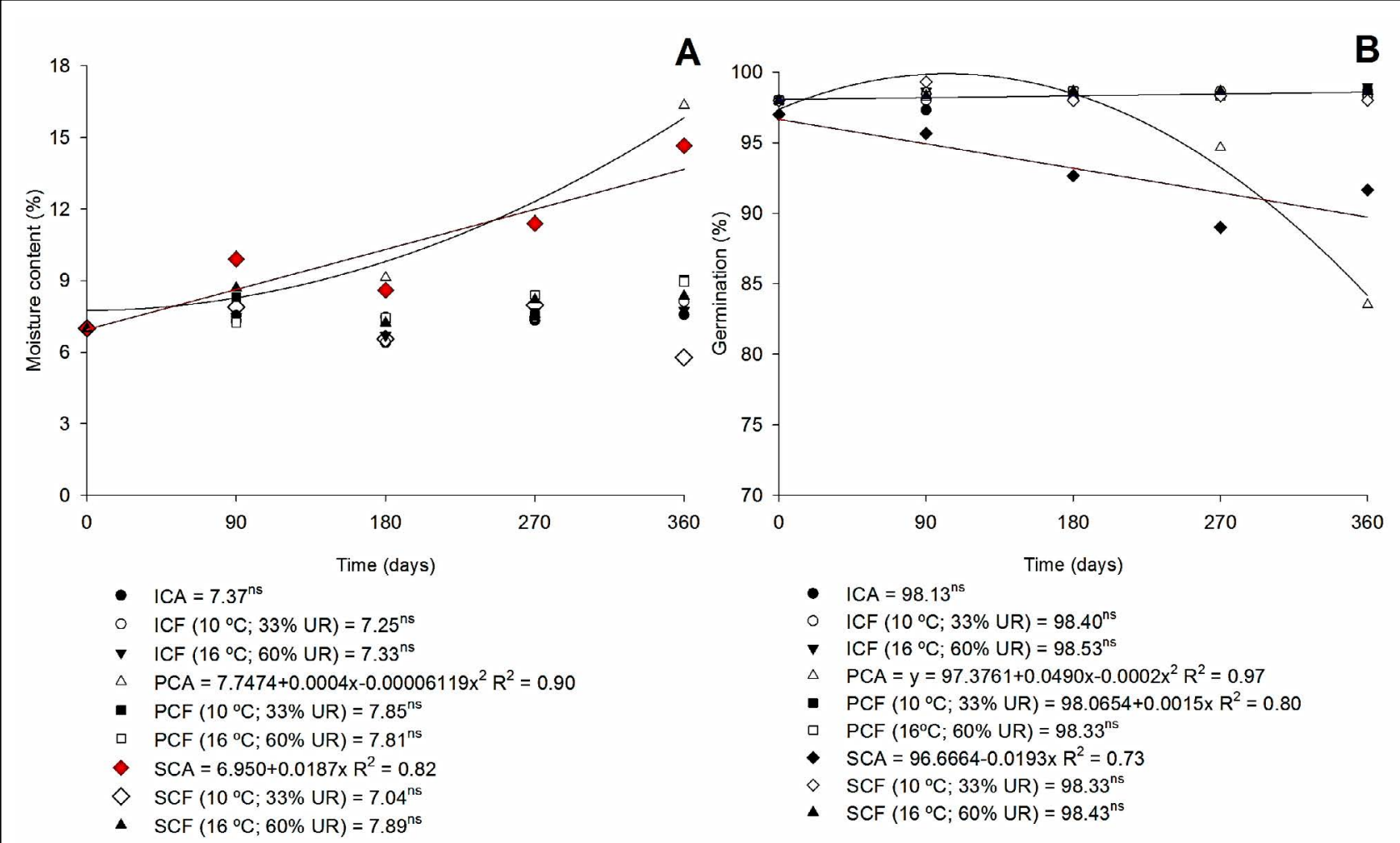

Figure 1. Moisture content (A) and germination (B) of onion seeds stored under different environments, packings and storage periods. PCA, ICA and SCA = permeable, impermeable and semi-permeable in environmental condition, respectively; ICF $=$ impermeable in cold chamber $\left(10^{\circ} \mathrm{C}\right.$ and $\left.33 \% \mathrm{UR}\right)$; and ICF $=$ impermeable in cold chamber $\left(16^{\circ} \mathrm{C}\right.$ and $\left.60 \% \mathrm{UR}\right) . \mathrm{PCF}=$ permeable in cold chamber $\left(10^{\circ} \mathrm{C}\right.$ and 33\% UR). Pelotas, UFPel, 2018.

and the statistical model to better explain the obtained results was determined. Thus, for semi-permeable packing, linear behavior was observed and, for permeable packing, quadratic behavior was verified. After determining statistical models, we considered only the equations which showed a coefficient of determination of, at least, $90 \%\left(\mathrm{R}^{2}>0.90\right)$. Thus, the equations using an adjusted regression model would explain more than $90 \%$ of the total variation found in the data set. The other ways to store seeds did not result in significant changes in moisture content. According to Baudet \& Villela (2019), when stored in permeable packing, the seeds suffer a change in moisture content during storage due to variations in air relative humidity, since they are hygroscopic.

The seeds in an uncontrolled environment and semi-permeable packing showed an increase in moisture content $(6.68 \%)$ up to 360 days of storage (Figure 1A), whereas, during the same period, the seeds stored in an uncontrolled environment using impermeable packing showed maintenance of moisture content and those seeds stored in permeable packing showed a reduction in moisture content up to 33 days of storage, with a subsequent increase up to 360 days.

In relation to germination test (Figure 1B), linear equations with increasing effect were adjusted for semipermeable and permeable packings under environmental conditions, and the quadratic equation for permeable packing was a statistical model better explaining the obtained results. The seeds in permeable packing showed a reduction in germination, presenting a minimum value of approximately $90 \%$ at 360 days. According to Smaniotto et al. (2014), the seeds lose their germination capacity due to lipid peroxidation, variations in moisture content and temperature of the seed mass, since they depend on storage conditions. The seeds stored in semi-permeable packings kept viability above $91 \%$, up to 360 days (Table 1). Moreover, considering time with types of packing and uncontrolled storage environment, the seeds showed, practically, the same germination throughout storage (Figure 1B).

In relation to first germination count (PCG), in all periods, associated with uncontrolled environment and semipermeable and permeable packings, respectively, decreasing quadratic and linear behavior was observed, being the polynomial models the ones which best explain the obtained results (Figure 2A). On the other hand, the seeds in impermeable packings did not significantly reduce in different periods, regardless of their storage environment.

After evaluating the unfolding of the triple interaction for IVG and after determining the statistical models for polynomial regression equations, combinations of environment and packing represented quadratic behavior in different periods, except for, only, combinations of uncontrolled environment and semi-permeable and permeable packings, which showed 


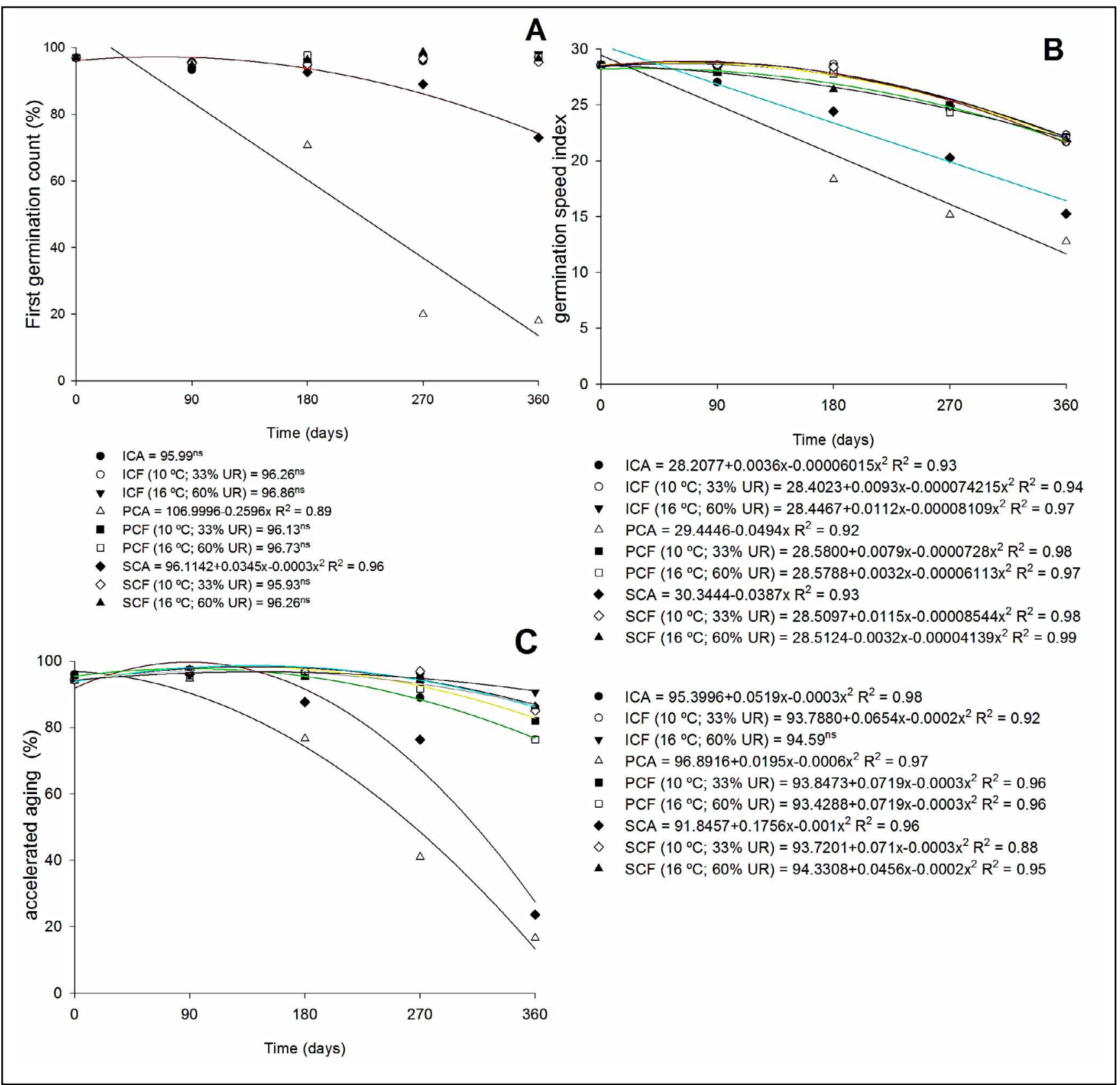

Figure 2. First germination count (A), germination speed index (B), accelerated aging (C) of onion seeds stored under different environments, packings and storage periods. PCA, ICA and SCA = permeable, impermeable and semi-permeable in environmental condition, respectively; $\mathrm{ICF}=$ impermeable in cold chamber $\left(10^{\circ} \mathrm{C}\right.$ and $\left.33 \% \mathrm{UR}\right)$; and ICF $=$ impermeable in cold chamber $\left(16^{\circ} \mathrm{C}\right.$ and $60 \%$ UR $)$. Pelotas, UFPel, 2018.

decreasing linear behavior (Figure 2B), with reductions of $60.40 \%$ and $45.91 \%$, respectively. Among other factors, when stored, the seeds started to germinate slower than the new seeds, as they breathe more slowly and become more susceptible to disease, accumulating chromosomal abnormalities and emitting abnormal seedlings (Antonello et al., 2009).

Evaluations used to obtain vigor of seeds through accelerated aging test showed that, except for the combination of $16^{\circ} \mathrm{C}$ and $60 \%$ UR and impermeable packing, results were not significant. In the other environments and packings, a quadratic behavior throughout storage was observed (Figure 2C), with a tendency to a brief reduction in vigor, which may be closely related to the quality of the impermeable packing, which inhibits gas exchange, making that seeds keep their breathing almost inert (Felix et al., 2017). Still, concerning the accelerated aging test, the stored seeds in an uncontrolled environment kept in impermeable packing showed performance similar to those stored in controlled environments.

Similar results obtained in this study were observed by Silva et al. (2010); they observed that seeds of rice, maize and beans, stored in permeable packings at room temperature, showed the lowest quality indexes at the end of storage, when compared with indexes 
of the seeds in impermeable packings. According to Marcos Filho (2015), vigor maintenance can be related to moisture variations observed according to the hermetic packages used and $\mathrm{O}_{2}$ concentration inside the packings, which interfere with the seeds' metabolism.

For seedling emergence, the bifactor analysis (packing $\mathrm{x}$ environment) was used. A significant difference only for permeable packing in an uncontrolled environment (Table 2) was noticed, considering that in the other packings, the seeds and seedlings showed higher vigor, being stored in an uncontrolled environment. Similar results were obtained by Natubhai et al. (2018) using onion seeds and packings made of plastic, paper and cotton, since in controlled environments and packings, seed physiological quality was maintained, resulting in similar seedling emergence values.

Evaluating seedling emergence in onion seeds, Rao et al. (2006) noticed that the seed vigor reduced gradually with the extension of storage time. However, vigor loss was accentuated in seeds stored in an uncontrolled environment, whereas vigor decline was relatively stable when stored at $25^{\circ} \mathrm{C}$.

Overall, the maintenance of seed physiological quality was verified in impermeable packing, regardless of the storage environment, as well as in impermeable or permeable packings under controlled environment. Thus, the authors suggest that storage should be carried out in impermeable packings and $7 \%$ moisture, regardless of the storage environment. Semi-permeable and permeable packings were efficient to store seeds under controlled conditions, in cold chamber or cold and dry chamber. Impermeable packings maintained seed physiological quality up to 360 days, regardless the storage environment.

\section{REFERENCES}

ANTONELLO, LM; MUNIZ, MB; BRAND, SC; VIDAL, MD; GARCIA, D; RIBEIRO, L; SANTOS, V. 2009. Qualidade de sementes de milho armazenadas em diferentes embalagens. Ciência Rural 39: 2191-2194.

BAUDET, LML; VILLELA, FA. 2019. Armazenamento de sementes. In: PESKE, ST; VILLELA, FA; MENEGHELLO, GE (eds). Sementes: fundamentos cientificos $e$ tecnológicos. Pelotas: Ed. Becker e Peske, p.481-528.

BRASIL. Ministério da Agricultura, Pecuária e Abastecimento. 2009. Regras para Análise de Sementes. Secretaria de Defesa Agropecuária. Brasília: MAPA/ACS, 399p.

BRASIL. Portaria SDA n ${ }^{\circ} 42$, de 17 de setembro de 2019. Normas para a produção e a comercialização de sementes e mudas de espécies olericolas, condimentares, medicinais e aromáticas e os seus padrões de sementes. Diário Oficial da União, Brasília, September 17, 2019. Seção 1. 6p.

CATÃO, HCRM; GOMES, LAA; GUIMARÃES, RM; FONSECA, PHF; CAIXETA, F; GALVÃO, AG. 2018. Physiological and biochemical changes in lettuce seeds during storage at different temperatures. Horticultura Brasileira 36: 118-125.

COSTA, LM; RESENDE, O; GONÇALVES, DN; SOUSA, KA. 2012. Qualidade dos frutos de crambe durante o armazenamento. Revista Brasileira de Sementes 34: 239-301.

FELIX, FC; PÁDUA, GVG; ARAÚJO, FS; FERRARI, CS; PACHECO, MV. 2017. Armazenamento de sementes de Pritchardia pacifica. Revista de Ciências Agrárias 40: 69-78.

GONZÁLEZ,JD; FERNÁNDEZ, BB; CARREÑO FS. 2012. Influência de diferentes métodos de conservación en la germinación de semillas de palma areca (Dypsis lutescens, H. Wendel). Cultivos Tropicales 33: 56-60.

GROOT, SPC; SURKI, AA; VOS, RCH; KODDE, J. 2012. Seed storage at elevated partial pressure of oxigen, a fast method for analyzing seed ageing under dry conditions. Annals of Botany 110: 1149-1159.

IBGE - Instituto Brasileiro de Geografia e Estatística. 2018. Produção Agrícola Municipal - 2018. Available at $<$ https://sidra. ibge.gov.br/pesquisa/pam/tabelas $>$. Accessed March 19, 2020.

JIANHUA, Z; McDONALD, MB. 1996. The saturated salt accelerated aging test for smallseeded crops. Seed Science \& Technology 25:
123-131.

JOSÉ, SCBR; SALOMÃO, AN; COSTA, TS; SILVA, JTTT; CURI, CCS. 2010. Armazenamento de sementes de girassol em temperaturas subzero: aspectos fisiológicos e bioquímicos. Revista Brasileira de Sementes 32: 29-38.

LEITE, DL. 2014. Produção de sementes de cebola. Circular Técnica, v. 142, p. 1-9.

MAGUIRE, JD. 1962. Speed of germination aid in selection and evaluation for seedling emergence and vigor. Crop Science 2: 176-77.

MARCOS FILHO, J. 2015. Fisiologia de sementes de plantas cultivadas. 2. ed. Piracicaba: FEALQ. 660p.

MARTINS, ABN; XAVIER, FN; DIAS, LW; MENEGUZZO, MRR; VERA, MJG; MORAES, DM. 2017. Qualidade fisiológica de lotes de sementes de amaranto. Revista CONGREGA URCAMP 14: 2433-2440.

MONCALEANO-ESCANDON, J; SILVA, BCF; SILVA, SRS; GRANJA, JAA; ALVES, MCJL; POMPELLI, MF. 2013. Germination responses of Jatropha curcas L. seeds to storage and aging. Industrial Crops and Products 44: 684-690.

NATUBHAI, B; PATIL, K; KARJULE, AP; PATEL, DA. 2018. Effect of containers and duration on seed quality of onion under ambient storage conditions. Seed Research Journal 45: 1-4.

RAO, RGS; SINGH, PM; RAI, M. 2006. Storability of onion seeds and effects of packaging and storage conditions on viability and vigour. Scientia Horticulturae 110: 1-6.

SILVA, FS; PORTO, AG; PASCUALI, LC; SILVA, FTC. 2010. Viabilidade do armazenamento de sementes em diferentes embalagens para pequenas propriedades rurais. Revista de Ciências AgroAmbientais 8: 45-56.

SMANIOTTO, TAS; RESENDE, O; MARÇAL, KAF; OLIVEIRA, DEC; SIMON, GA. 2014. Qualidade fisiológica de sementes de soja armazenadas em diferentes condições. Revista Brasileira de Engenharia Agrícola e Ambiental 18: 446-453.

TONIN, GA; PEREZ, SCJGA. 2006. Qualidade fisiológica de sementes de Ocotea porosa (Nees et Martius ex. Nees) após diferentes condições de armazenamento e semeadura. Revista Brasileira de Sementes 28: 26-33.

UMESHA， U; VASUDEVAN, SN; BHANUPRAKASH, K; MANJUNATHA, B; SARIKA, G; AMRUTA, N. 2016. Biochemical investigations on vigour enhancement in aged seeds upon seed priming in onion. Journal of Applied and Natural Science 8: 855-859. 